\title{
STUDIES ON VARIOUS FUNCTIONAL PROPERTIES OF TITANIA THIN FILM DEVELOPED ON GLAZED CERAMIC WALL TILES
}

\author{
ASHA ANIL ${ }^{* 1}$ \\ ashata.36@gmail.com \\ BANGORIA DARSHANA $\mathrm{R}^{2}$ \\ KSKV Kachh University, Gujarat \\ S. N. MISRA ${ }^{3}$ \\ CSIR-Central Glass \& Ceramic Research Institute, Naroda Centre, ${ }^{1 \& 3}$ \\ Naroda Industrial Estate, Ahmedabad-382 330, Gujarat, India \\ siccgcrinc@gmail.com
}

\begin{abstract}
A sol-gel based $\mathrm{TiO}_{2}$ thin film was applied on glazed wall tiles for studying its various functional properties. Thin film was deposited by spin coating on the substrate and subjected to curing at different temperatures such as $600^{\circ} \mathrm{C}, 650,700^{\circ} \mathrm{C}, 750^{\circ} \mathrm{C}$ and $800^{\circ} \mathrm{C}$ with 10 minutes soaking. The gel powder was characterized by FTIR, DTA/TG and XRD. Microstructure of thin film was analyzed by FESEM and EDX. Surface properties of the coatings such as gloss, colour difference, stain resistance, mineral hardness and wettability were extensively studied. The antibacterial activity of the surface of coated substrate against E. coli was also examined. The durability of the coated substrate in comparison to the uncoated was tested against alkali in accordance with ISO: 10545 (Part 13):1995 standard. FESEM images showed that thin films are dense and homogeneous. Coated substrates after firing results in lustre with high gloss, which increased from 330 to $420 \mathrm{GU}$ as the curing temperature increases compared to that of uncoated one (72 GU). Coated substrate cured at $800^{\circ} \mathrm{C}$ shows higher mineral hardness (5 Mohs') compared to uncoated one (4 Mohs') and films cured at all temperatures showed stain resistance. The experimental results showed that the resistance towards alkali attack increase with increase in curing temperature and alkali resistance of sample cured at $800{ }^{\circ} \mathrm{C}$ was found to be superior compared to uncoated substrate. Contact angle of water on coated surface of substrates decreased with increase in temperature. Bacterial reduction percentages of the coated surface was $97 \%$ for sample cured at $700^{\circ} \mathrm{C}$ and it decreased from $97 \%$ to $87 \%$ as the curing temperature increased to $800{ }^{\circ} \mathrm{C}$ when treated with E. coli bacteria.
\end{abstract}

Keywords: $\mathrm{TiO}_{2}$ coatings; glazed wall tiles; functional properties; chemical resistance.

\section{Introduction}

$\mathrm{TiO}_{2}$ is a semiconductor and it is well known for its photocatalytic properties such as hydrophilicity, oxidizing power to decompose organic contaminants such as grease, dirt, bacteria etc. In recent years, this property of $\mathrm{TiO}_{2}$ has been applied to important problems of environmental interests like detoxification of water, decomposing pollutants in air etc. 
As studies showed that oxide based thin films coating can modify properties of various substrates, nano $\mathrm{TiO}_{2}$ thin films were applied to get antifogging ${ }^{1}$, antibacterial ${ }^{2-3}$, selfsterilizing ${ }^{4-5}$ self-cleaning effect ${ }^{6}$ etc. on various substrates such as glass, glazed ceramic surfaces etc. $\mathrm{TiO}_{2}$ is also known for its optical applications due to its high refractive index. Nowadays, studies on fixing these nano $\mathrm{TiO}_{2}$ thin film on glazed ceramic surfaces is also taking place ${ }^{7-15}$, as these tiles are also exposed to bacteria, pollutants, dust, dirt, oil etc. in hospitals, commercial and domestic places. Application of these thin film coatings could reduce infections and household work for cleaning by reducing time and cost of the cleaning agents and thereby improving surrounding hygiene. Literature shows that investigations on some specific properties of $\mathrm{TiO}_{2}$ coated glazed ceramic wares such as gloss and wear resistance ${ }^{7}$, antibacterial ${ }^{8-11}$, cleanability and chemical resistance ${ }^{12-16}$ of sol-gel based $\mathrm{TiO}_{2}$ thin film were studied separately. However, to best of our knowledge, no one has done a systematic study on surface characteristics of the coated substrates in all aspects. Hence, the present work reports effect of curing temperature on surface characteristics of sol-gel based $\mathrm{TiO}_{2}$ thin film deposited glazed ceramic wall tiles. These properties include gloss, colour difference, stain resistance, mineral hardness, wettability, antibacterial activity and alkali resistance in highly alkaline $\mathrm{KOH}$ solution.

\section{Experimental Procedure}

\subsection{Sol preparation and sample preparation}

The precursor used for titania sol preparation was technical grade titaniumtetraisopropoxide (TTIP) (M/s Sigma-Aldrich Chemie GmbH, Germany). For preparing $1.5 \mathrm{wt}$. $\% \mathrm{TiO}_{2}$ sol, acetyl acetone (M/s Merck Specialities Pvt. Ltd., Mumbai) was used as complexing agent, in order to control the hydrolysis rate and double distilled water was added as hydrolysing agent. The molar ratio of TTIP, acetyl acetone and water was kept as 1:2:4. The weight percentage of $\mathrm{TiO}_{2}$ in the sol was fixed by adding required amount of Iso-propyl alcohol (M/s Astron Chemicals, Ahmedabad, Gujarat). The method of preparation of $1.5 \mathrm{wt} . \% \mathrm{TiO}_{2}$ sol involved mixing required amount of TTIP and acetyl acetone on a magnetic stirrer at room temperature for around 30 minutes and finally adding necessary amount of water and isopropyl alcohol. This mixture was allowed to stir for 1 hour in order to ensure proper mixing of the chemicals and aged for 2 days.

Substrate taken for study was glazed ceramic wall tiles covered with white glossy glaze sourced from a tile company in Gujarat. The samples of glazed ceramic tiles were carefully cleaned by detergent to remove oily residues followed by washing with distilled water and a soft cotton cloth moistened with alcohol and then dried at $150^{\circ} \mathrm{C}$ and cooled to room temperature. Thin film coating was deposited by the spin-coating method ( 800 rpm for $30 \mathrm{sec}$ ) onto $80 \times 80 \mathrm{~mm}$ plates cut out from tile sample by a laboratory made spinning machine. The amount of applied sol was $1.5 \mathrm{ml} / 4$ " X 4" tile size. The coated samples were fired in a Roller Hearth furnace (M/s. V.B. Ceramic Consultants, Chennai, India) at a heating rate of $20^{\circ} \mathrm{C}$ with a 10 minutes soaking time in peak firing 
temperatures of $600^{\circ} \mathrm{C}, 650^{\circ} \mathrm{C}, 700^{\circ} \mathrm{C}, 750^{\circ} \mathrm{C}$ and $800^{\circ} \mathrm{C}$ temperatures and the sample thereinafter mentioned as T-600, T-650, T-700, T-750 and T-800 respectively.

After firing, rectangular pieces of $80 \mathrm{~mm}$ in length and $40 \mathrm{~mm}$ in breadth were cut from the piece using a ceramic tile cutter using a diamond wheel. The uncoated tile pieces with the same dimension as mentioned above were also cut for comparative studies. Theses pieces were used for the subsequent characterization and assessment of alkali attack in immersion.

\subsection{Characterization of gel powder}

Gel powder sample was prepared by drying the sol at $150^{\circ} \mathrm{C}$ in an air bath, then ground in an agate mortar, and used for the following studies.

\subsubsection{FTIR analysis}

FTIR analysis was carried out for determining different types of bonding in the gel. $\mathrm{KBr}$ pellets were made using gel dried powder for FTIR measurement using Fourier transform Infrared spectroscopy (Spectrum 100, Perkin Elmer, USA) ranging from $400 \mathrm{~cm}^{-1}$ to 4000 $\mathrm{cm}^{-1}$.

\subsection{2. $T G-D T A$}

TG-DTA of the dried gel was carried out by TG-DTA Analyzer, Model No. 6300 (Seiko Instruments Inc, Japan) at a heating rate of $20^{\circ} \mathrm{C} /$ minute from room temperature to $1000^{\circ} \mathrm{C}$.

\subsection{3. $X R D$}

The XRD patterns obtained in a Philip's X-ray crystallographic unit (Model PW-1730) with a Goniometer $\mathrm{PW}-1710$ in the $2 \theta$ range $10-90^{\circ}$ using $\mathrm{CuK} \alpha$ radiation $\left(\lambda=1.5 \mathrm{~A}^{\circ}\right)$ were used to investigate the phase analysis and transformation of the gel powder samples calcined at $450^{\circ} \mathrm{C}, 600^{\circ} \mathrm{C}, 700^{\circ} \mathrm{C}$, and $800^{\circ} \mathrm{C}$.

\subsection{Thin film characterization}

\subsubsection{FE-SEM and EDX}

The thickness as well as the surface microstructure of the thin film applied over glazed layer of tiles cured at different temperatures was determined by 'Field Emission Scanning Electron Microscope coupled with link ISIS EDX detector (Model Supra 35VP, Carl Zeiss, Germany)'. The thickness of the film on the glaze was measured from a crosssectional view of fractured sample. EDX mapping of thin film and glaze layer of (crosssectional view) coated substrates cured at $700{ }^{\circ} \mathrm{C}, 750{ }^{\circ} \mathrm{C}$ (not shown) and $800^{\circ} \mathrm{C}$ (shown) were carried out. 


\subsubsection{Colour difference $(\Delta E)$}

The colour difference was measured using Konica Minolta Spectrophotometer, Model CM-3600d and with measurement area of $8 \mathrm{~mm}$ under d/o SCI optical geometry as per ASTM C $609-90{ }^{17}$. The values in terms of CIE $\Delta \mathrm{E}$ have been measured and the average of 5 measurements has been furnished.

\subsubsection{Gloss}

Gloss is an optical property, refers to the ability of a surface to reflect light in specular direction and depends on many parameters such as refractive index of the material, the angle of incidence of light, surface topography etc. Specular reflection is the perfect mirror like reflection of light from a surface in which light from a single incoming direction is reflected into a single outgoing direction. Reflection is a fundamental optical phenomenon, which occurs when light propagates across a boundary between two media that have different refractive indices ${ }^{18}$.

The gloss of the test specimens were measured by Novagloss ${ }^{\mathrm{TM}}$ Statistical Glossmeter (Rhopoint Instrumentation Ltd., U.K) with an angle of $20^{\circ}$, calibrated using a reference polished black glass with a gloss of $88.8 \mathrm{GU}$ at an angle of $20^{\circ}$. This was as per standard ASTM test method (D523-89) ${ }^{19}$, which relates the light reflected from the test specimens to that reflected from the black glass. All gloss readings are given in Gloss Units (GU).

\subsubsection{Wettability}

The wettability of the films was evaluated by examining the contact angle of water on $\mathrm{TiO}_{2}$ coated surface. The static contact angle of water on coated specimens was measured by contact angle analyzer (Model, phoenix 300, Korea).

\subsubsection{Mineral Hardness}

The surface hardness test of coated tiles was measured in terms of Mohs' hardness scale. The test is performed by drawing minerals of defined hardness over the surface of the tile (different minerals having hardness ranging from 1 to 10 in the moh's scale) by hand and subjectively assigning a Mohs' number to the glazed tile. The mineral of highest Moh's hardness that produces not more than one scratch is reported.

\subsubsection{Stain resistance}

The stain resistance of coated tile was carried out by exposing the coated surface to $1 \%$ Methylene blue solution for $24 \mathrm{~h}$ and washed with water to remove the same. If there is no stain mark after washing, then it can be reported as stain resistant. 


\subsubsection{Alkali resistance test}

The alkali resistance of the coated substrates were performed in accordance with ISO: 10545 (Part 13): $1995^{20}$. The test includes immersion of the test specimens in 10wt. \% $\mathrm{KOH}$ for 4 days at $25^{\circ} \mathrm{C}$ and is often classified by visual assessment. However, in the present study, alkali resistance was evaluated quantitatively by gloss measurement before and after immersing the samples in alkali solution. The tile specimens were removed, washed and dried at an interval of $24 \mathrm{~h}$ for gloss measurements. Five pieces of each coated piece fired at each temperature were used for the study. To remove any error in gloss values, frequent calibration checks were made throughout the experiments and the measurement area was marked and positioned in the same way after each intervals of time.

\subsubsection{Antibacterial activity test}

Escherichia coli were used for the antibacterial activity test of the samples and the test was carried out as per JIS Z 2801:2000 ${ }^{21}$. A bacterial suspension of E. coli was prepared by cultivating the bacteria for one night, washing and then diluting the solution so that the initial bacterial count was around 8 to $10 \times 10^{5}$ colony forming units $(\mathrm{CFU}) / \mathrm{mL}$. The surface of the substrate was sterilized by alcohol and dried, then dripped with $0.4 \mathrm{ml}$ of the bacterial suspension. The tile was covered with non-alkaline glass to improve contact of the bacterial suspension with the surface and to prevent suspension from drying. The sample was irradiated for $30 \mathrm{~min}$ under UV light. The suspension was collected on a petri dish, to cultivate the bacteria, for $\sim 24 \mathrm{~h}$ at $35 \pm 1^{\circ} \mathrm{C}$, so that bacterial colonies would form. The number of living bacteria was counted. Bacterial reduction rate was obtained by comparing the number of living bacteria on the examined tile sample with that of a conventional tile sample. The glazed surface of conventional tile without $\mathrm{TiO}_{2}$ coating was tested as a control sample.

\section{Results and Discussions}

\subsection{Characterization of gel powder}

\subsubsection{FTIR}

As shown as in Fig.1., the dried gel presented a large band centered at $3430 \mathrm{~cm}^{-1}$ corresponding to lattice water absorbed (anti symmetric and symmetric $\mathrm{OH}$ stretching) ${ }^{22}$. The two very small bands present at $2923 \mathrm{~cm}^{-1}$ and $2852 \mathrm{~cm}^{-1}$ in the spectrum of dried gel are due to $\mathrm{CH}_{2}$ anti symmetric stretching and symmetric stretching of $\mathrm{C}-\mathrm{H}$ bond respectively. The strong bands at 1585 and $1531 \mathrm{~cm}^{-1}$ are due to AcAc groups bonded to titanium $^{22-23}$. In the spectra of our gel, IR bands due to titanium isopropoxide at $620 \mathrm{~cm}^{-1}$ assigned to Ti-O -Pr and CO stretching metal alkoxide at $1029 \mathrm{~cm}^{-1}$ are also observed. The characteristic band of Ti-O-Ti $\left(436-495 \mathrm{~cm}^{-1}\right)$ is also observed. 


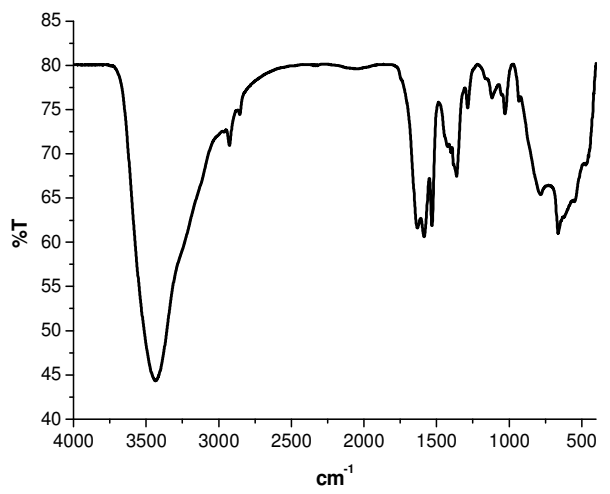

Fig.1. FTIR spectrum of the dried gel.

\subsubsection{TG-DTA}

TG-DTA of air dried gel sample in Fig.2. demonstrates that thermal decomposition continued till $575^{\circ} \mathrm{C}$. During heating, there was continuous weight loss of $42 \%$ up to $650^{\circ} \mathrm{C}$ indicating decomposition of volatiles present in the gel material. DTA curve revealed that endothermic reaction at a temperature of $125^{\circ} \mathrm{C}$ is mostly owing to evaporation of physical water and volatile organic components and at a higher temperature (i.e. from $200^{\circ} \mathrm{C}$ onwards) decomposition of carbonaceous material from the organic metallic complex takes place leading to exothermic reaction in presence of air. Major broad exothermic peaks at $309.09^{\circ} \mathrm{C}$ is due to decomposition of carbonaceous material and exothermic peak at $454.40^{\circ} \mathrm{C}$ is due to crystallization of titania as supported by the observations from the X-ray diffraction pattern of gel (Fig. 3) which gave welldefined anatase peaks. The minor peaks at $476.21^{\circ} \mathrm{C}$ could be attributed to anatase to rutile phase transformation.

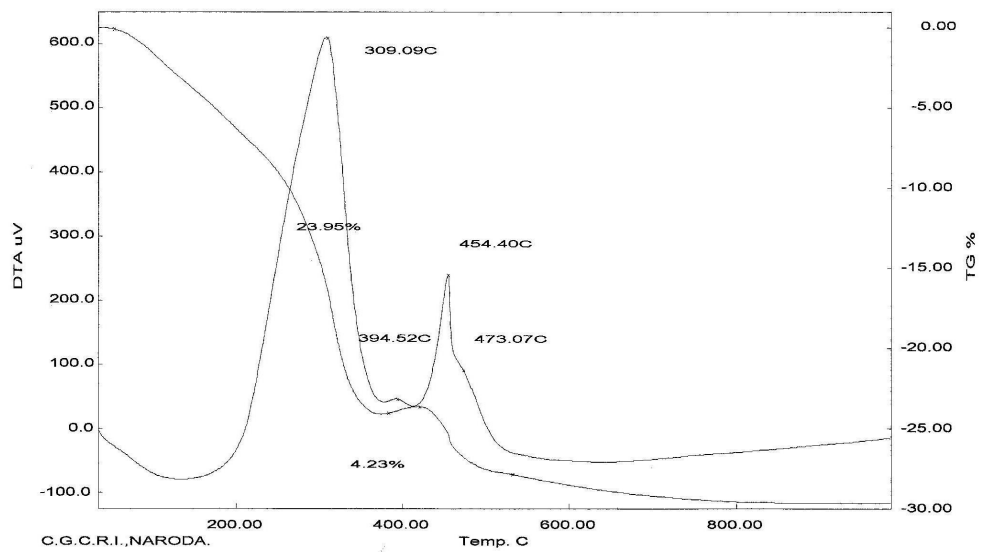

Fig. 2. TG-DTA of air dried gel. 


\subsection{3. $X R D$}

XRD patterns obtained from the calcined powders of the gel having same composition as that of the thin film are shown in Fig.3. The patterns labeled T-450, T-600, T-700 and T800 represent the $\mathrm{TiO}_{2}$ gel powder after calcinations at $450,600^{\circ} \mathrm{C}, 700^{\circ} \mathrm{C}$ and $800^{\circ} \mathrm{C}$ respectively. It can be seen that strong peak at $2 \theta=25.3^{\circ}$ which corresponds to the (101) crystal plane for T-450, confirms crystallization of anatase. At $600^{\circ} \mathrm{C}$, it was observed that rutile phase [strong peak at $2 \theta=27.4^{\circ}$ which corresponds to the (110) crystal plane] predominate over anatase phase. As the temperature increases from $600^{\circ} \mathrm{C}$ to $700^{\circ} \mathrm{C}$, intensity of anatase phase reduced and rutile phase increased. However, at $800{ }^{\circ} \mathrm{C}$, titania was completely transformed to rutile phase.

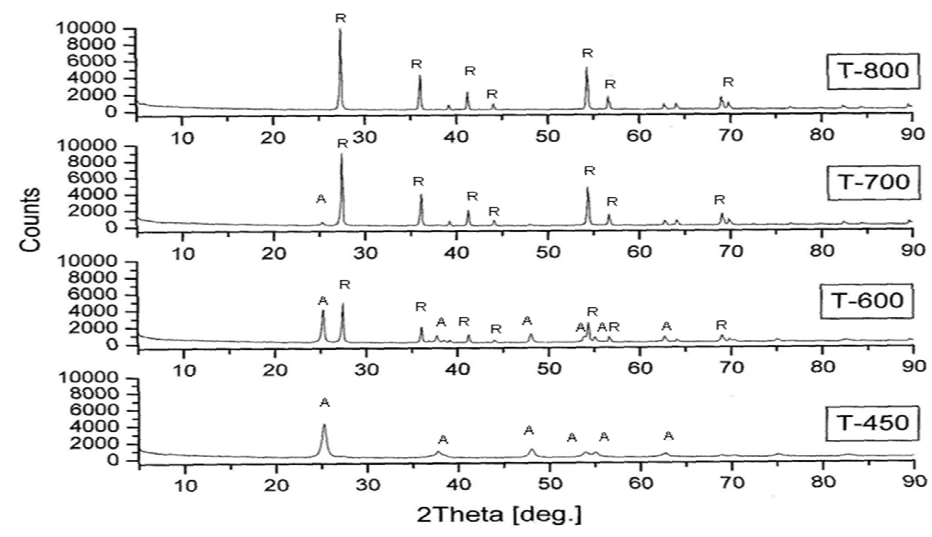

Fig.3. X-ray diffraction pattern of gel calcined at different temperatures

\subsection{Thin film characterization}

The deposited film was observed as crack free and homogeneous after curing at test temperatures.

\subsubsection{FESEM study}

Titania thin film cured at $600^{\circ} \mathrm{C}$ was found to be completely wiped out after rubbing with hand or tissue paper and those cured at $650^{\circ} \mathrm{C}$ was found to be too soft as it shows a lot of scratches after rubbing with hand on the film. Hence, sample cured at $700^{\circ} \mathrm{C}, 750^{\circ} \mathrm{C}$ and $800^{\circ} \mathrm{C}$ was only taken for FESEM study.

Cross-sectional image of the thin film coated glazed ceramic tile cured at $750^{\circ} \mathrm{C}$ and $800{ }^{\circ} \mathrm{C}$ are depicted in Fig.4a and 4b. Thickness of the applied coating of T750 and T800 is found to be about $\sim 63 \mathrm{~nm}$ and $\sim 50 \mathrm{~nm}$ respectively. In Fig. $4 \mathrm{a}$ and $4 \mathrm{~b}$, interface boundary between applied coating and glaze (zircon crystals embedded in glassy matrix) can be distinguished on the basis of their micro structural difference. 

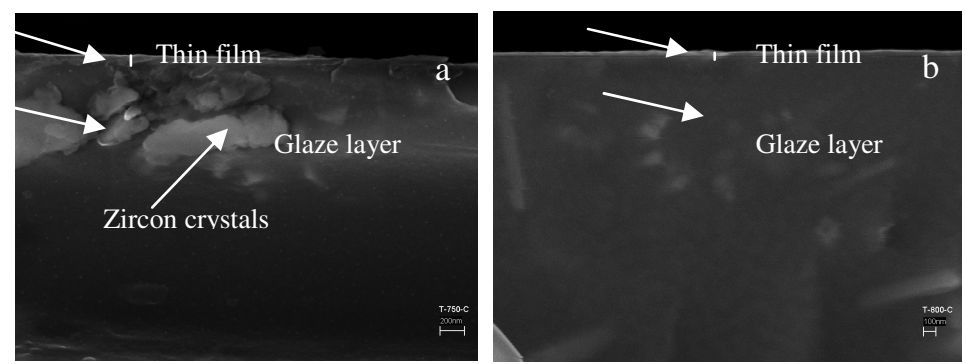

Fig.4. FESEM images of cross-section of $\mathrm{TiO}_{2}$ thin film coated substrate cured at (a) $750^{\circ} \mathrm{C}$ and (b) $800{ }^{\circ} \mathrm{C}$.

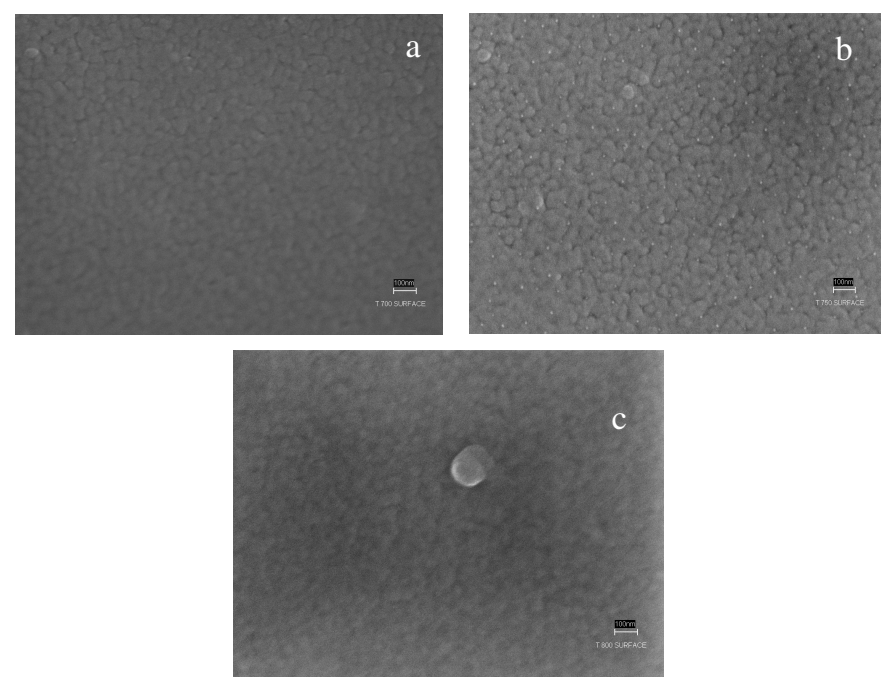

Fig.5. FESEM images of surface microstructures of $\mathrm{TiO}_{2}$ multi-oxide thin film coated substrate cured at (a) $700^{\circ} \mathrm{C}$, (b) $750^{\circ} \mathrm{C}$ and (c) $800{ }^{\circ} \mathrm{C}$.

Surface microstructures of thin film coating on T-700, T-750 and T-800 (coated tile fired at $700^{\circ} \mathrm{C}, 750^{\circ} \mathrm{C}$ and $800^{\circ} \mathrm{C}$ ) are shown in Figs. $5 \mathrm{a}, 5 \mathrm{~b}$ and $5 \mathrm{c}$. In the case of T-700 and T-750, nano-crystalline particles of titania are visible However, some precipitation of titania was also observed on T750. However, in the case of T800, nano particles are not clearly distinguished and it seems particles became immersed in glassy matrix of glaze which could be attributed to either softening of the glaze or film at $800^{\circ} \mathrm{C}$. The softening of film could be due to the presence of alkali ions diffused from glaze to the film as evident from EDX (Fig. 7). 


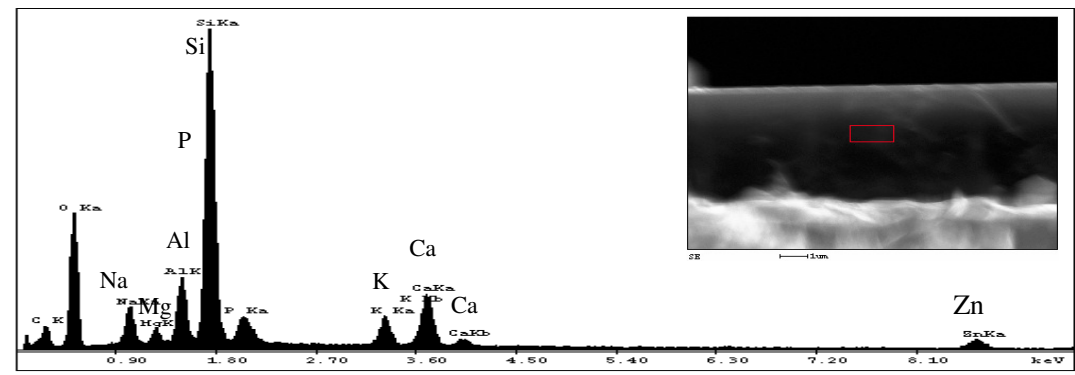

Fig.6. EDX of glaze layer of coated substrate cured at $800^{\circ} \mathrm{C}$ (marked position of glaze layer as shown in crosssectional image (inset) is mapped for EDX).

Energy Dispersive X-ray analysis of both the glaze and $\mathrm{TiO}_{2}$ thin film layer of coated substrate cured at $800^{\circ} \mathrm{C}$ are shown in Fig.6 and Fig.7 respectively. Fig.6 shows the presence of glaze elements such as $\mathrm{Na}, \mathrm{Mg}, \mathrm{Al}, \mathrm{Si}, \mathrm{K}, \mathrm{Ca}, \mathrm{Zn}, \mathrm{P}$ and $\mathrm{O}$ in the glaze layer of substrate. Presence of Ti besides other elements in glaze has been established from Fig.7, which ensures presence of titania thin film on the glaze layer. It is also established that the metal ions are diffused into the thin film layer due to which a low concentration of element in the glaze layer is also detected in the EDX of thin film (Fig.7). It is to be noted that film of T700 and T750 also showed all the components corresponds to glaze along with peaks of $\mathrm{Ti}$ (not shown).

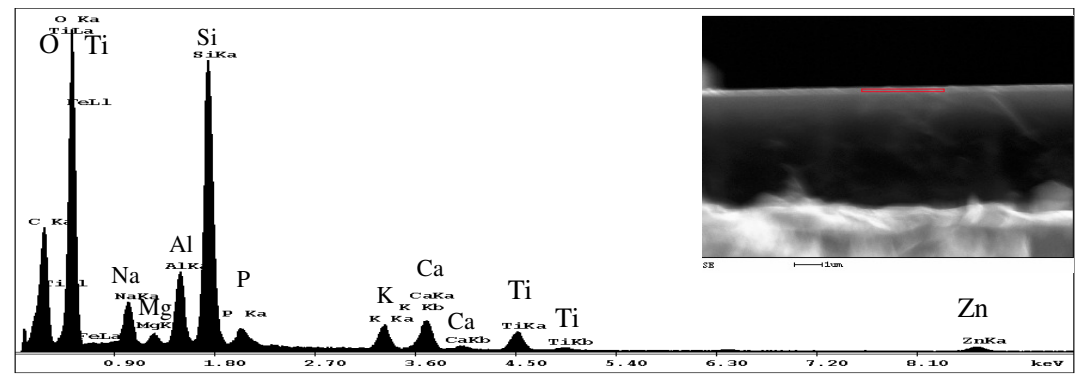

Fig.7. EDX of thin film portion of coated substrate cured at $800^{\circ} \mathrm{C}$ (marked position of thin film layer as shown in cross-sectional image (inset) is mapped for EDX).

Table 1. Colour difference between coated and uncoated substrates cured at different temperatures.

\begin{tabular}{llllll}
\hline $\begin{array}{l}\text { Sample } \\
\text { reference }\end{array}$ & T600 & T650 & T700 & T750 & T800 \\
\hline$\Delta \mathrm{E}$ & $0.35 \pm 0.2$ & $0.72 \pm 0.2$ & $0.68 \pm 0.2$ & $0.73 \pm 0.2$ & $0.93 \pm 0.2$ \\
\hline
\end{tabular}

\subsubsection{Colour difference $(\Delta E)$}

Thin film coated samples showed mirror like reflectivity after curing at all the temperatures. It is evident from the above table that coating has changed the colour of the 
coated tiles by a factor which ranges between $0.15-0.93$. However, it is marginal as the value is less than 1. CIE 1976 limiting value for colour difference between two samples of same colour is described as usually non-visible difference if $\Delta \mathrm{E}$ scale is found as $0<$ $\Delta \mathrm{E}<1^{24}$.

\subsubsection{Gloss}

It is evident from Fig.8. that the thin film coated substrates are having high gloss compared to uncoated one at all the curing temperatures and it increases with increase in curing temperature; especially from $750^{\circ} \mathrm{C}(390 \pm 20 \mathrm{GU})$ and showed maximum gloss for coated substrate cured at $800^{\circ} \mathrm{C}(420 \pm 20)$. The increase in gloss of the coated substrate is due to the high refractive index (2.4-2.6) of the coating compared to that of the glaze $(1.54-1.56)^{7}$ as it is also reported elsewhere ${ }^{7,18}$ that reflectivity of glass (gloss) surfaces can be increased simply by covering its surface with a single layer of metal oxide having a higher refractive index than that of glass and glaze is also a form of glass. The increase in gloss with increase in curing temperature could be attributed to phase transition from anatase to rutile with rise in temperature as evident from XRD results (Fig.3.). As per the literature ${ }^{25}$, rutile phase has high refractive index (2.6) compared to anatase phase (2.4) of $\mathrm{TiO}_{2}$. The increase in refractive index of the coating with increase in curing temperature could also be attributed to the increase in density of the film.

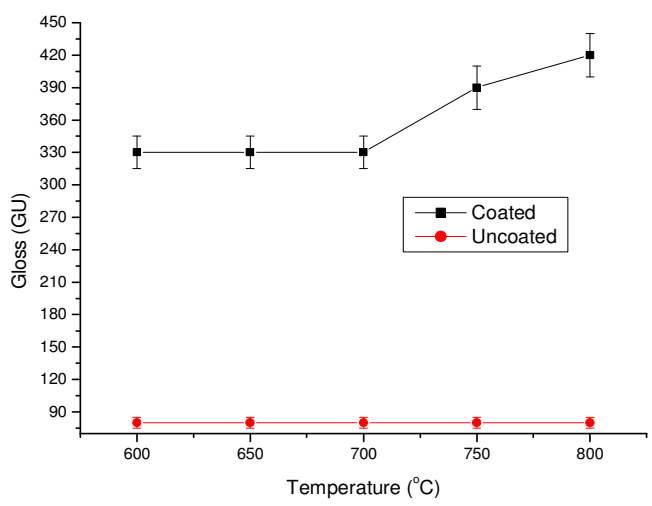

Fig.8. Effect of curing temperature on gloss of uncoated and coated substrates.

\subsubsection{Wettability of coated surface}

Table 2. shows contact angles of water on $\mathrm{TiO}_{2}$ film deposited substrates cured at different temperatures and uncoated. It was found that contact angle of water on T600 is higher than uncoated having a contact angle of $45 \pm 10$. However, as the curing temperature increases from $600{ }^{\circ} \mathrm{C}$ to $800^{\circ} \mathrm{C}$, it was found that contact angle slightly decreases, especially for samples cured at $750^{\circ} \mathrm{C}$ and $800^{\circ} \mathrm{C}^{26}$, which could be attributed to fine roughness generated on the surface of thin film at high temperature. This may be due to inter reaction between thin film and the glaze. It is known that wettability of a 
Table 2. Contact angle of water on the substrates under study.

\begin{tabular}{lll}
\hline $\begin{array}{l}\text { Sample } \\
\text { reference }\end{array}$ & $\begin{array}{l}\text { Curing } \\
\text { temperature }{ }^{\circ} \mathrm{C}\end{array}$ & $\begin{array}{l}\text { Contact Angle of } \\
\text { water }\left({ }^{\circ}\right)\end{array}$ \\
\hline Uncoated & N/A & $45 \pm 10$ \\
\hline T600 & 600 & $66 \pm 8$ \\
\hline $\mathrm{T} 650$ & 650 & $60 \pm 5$ \\
\hline $\mathrm{T} 700$ & 700 & $60 \pm 5$ \\
\hline $\mathrm{T} 750$ & 750 & $55 \pm 3$ \\
\hline $\mathrm{T} 800$ & 800 & $50 \pm 3$ \\
\hline
\end{tabular}

Table 3. Mineral hardness of coated and uncoated substrates.

\begin{tabular}{llc}
\hline $\begin{array}{l}\text { Sample } \\
\text { reference }\end{array}$ & $\begin{array}{l}\text { Curing } \\
\text { temperature }{ }^{\circ} \mathrm{C}\end{array}$ & $\begin{array}{l}\text { Mineral hardness } \\
\text { moh's scale }\end{array}$ \\
\hline Uncoated & N/A & 4 \\
\hline T600 & 600 & 2 \\
\hline T650 & 650 & 2 \\
\hline T700 & 700 & 3 \\
\hline T750 & 750 & 4 \\
\hline T800 & 800 & 5 \\
\hline
\end{tabular}

solid surface with liquids is not only governed by its chemical properties but also by its geometry ${ }^{27}$.

\subsubsection{Mineral hardness}

It is evident from Table-3 that with the increase in curing temperature, Mohs'mineral hardness of coated substrates increased as compared to the uncoated one. The uncoated substrate was having a hardness of 4 in Mohs' scale and coated tiles T600, T650 and T700 showed a hardness value, which is lower than that of uncoated substrate. The decrease in hardness of coated substrate cured at $600^{\circ} \mathrm{C}, 650^{\circ} \mathrm{C}$ and $700^{\circ} \mathrm{C}$ could be attributed to lack of proper adhesion of thin film on the substrate at these temperatures.

However, coated substrates cured at $750^{\circ} \mathrm{C}$ and $800^{\circ} \mathrm{C}$ showed a mineral hardness of 4 and 5 in Mohs' scale. The increase in hardness of the same could be attributed to densification and proper adhesion of the film on glazed surface due to softening of glaze at these temperatures. The relative hardness of glazed tile is an important issue that should be addressed when selecting a tile. Mineral that provides Moh's values of 3 (Min) is suitable for most residential wall applications as per the ISO standard ${ }^{20}$. It is evident from the table that test samples marked T700, T750 and T800 showed hardness values which meet the requirement of the standards.

\subsubsection{Stain resistance}

Studies showed that coated and uncoated substrate did not show any stain marks after washing out the methylene blue which was applied on the tile. This could be due to the presence of high dense film on the surface of coated substrate. 


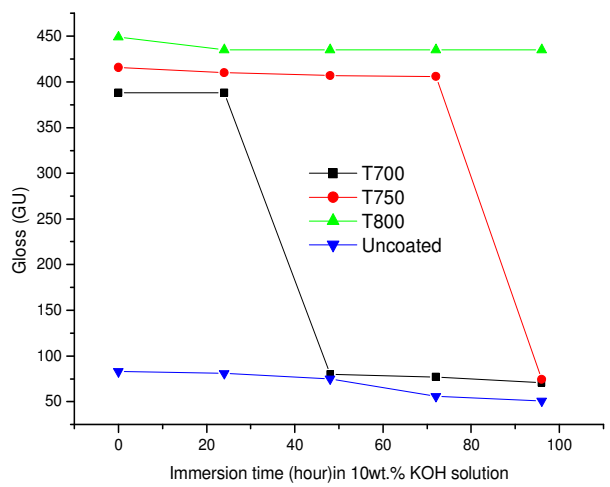

Fig.9. Alkali resistance of uncoated and coated substrate cured at $600^{\circ} \mathrm{C}, 700^{\circ} \mathrm{C}$ and $800^{\circ} \mathrm{C}$ as a function of immersing time in $\mathrm{KOH}$ soln. for $96 \mathrm{~h}$.

\subsubsection{Alkali resistance}

Fig.9. gives a comparison of alkali resistance of uncoated and $\mathrm{TiO}_{2}$ coated substrates cured at different temperatures against 10wt. \% KOH solution. T 600 and T650 were not taken for chemical resistance studies due to weak adhesion of the film. It is evident from Fig.9. that gloss of uncoated substrate reduced from $83 \mathrm{GU}$ to $51 \mathrm{GU}$ after $96 \mathrm{hrs}$ of immersion. It is also observed that T700 and T750 lost gloss after immersion in solution for $24 \mathrm{hrs}$ and $72 \mathrm{hrs}$ respectively and coating was found to be completely removed. It is also evident from Fig.9. that as the curing temperature increases, the alkali resistance of thin film increased and alkali resistance of $\mathrm{T} 800$ was found to be superior compared to uncoated substrate.

\subsubsection{Antibacterial activity}

Fig.10. shows the effect of the curing temperature on the antibacterial activity of $\mathrm{TiO}_{2}$ thin film coated glazed ceramic wall tiles. The antibacterial activity was tested by contact

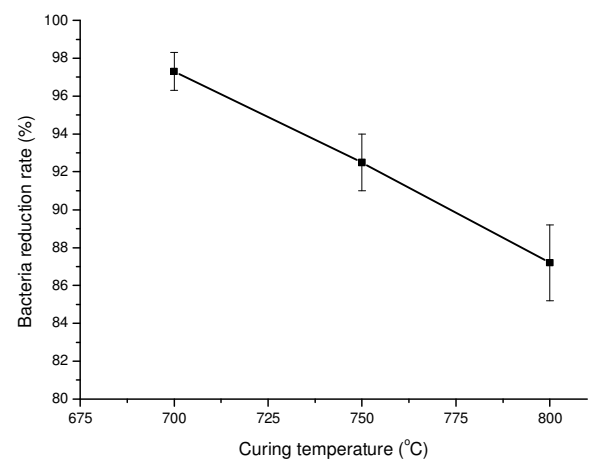

Fig.10. Effect of the curing temperature on the antibacterial activity $\mathrm{TiO}_{2}$ Thin film coated glazed ceramic wall tiles. 
between E. coli and the sample surface under UV light for $30 \mathrm{~min}$. As shown in Fig.10, antibacterial activity measured in terms of bacterial reduction percentages decreased from $97 \%$ to $87 \%$ when the curing temperature increased from $700^{\circ} \mathrm{C}$ to $800{ }^{\circ} \mathrm{C}$. The low antibacterial effect of sample cured at $800{ }^{\circ} \mathrm{C}$ could be attributed to the following reasons as reported earlier [10].

1. Photocatalytic property depends on the ratio of anatase to rutile. XRD results show that ratio of anatase to rutile phase decreased as the curing temperature increased.

2. The glaze might be softened and diffusion of glaze elements on to the thin film surface might be taken place at $800{ }^{\circ} \mathrm{C}$ as evident from EDX photographs.

\section{Conclusions}

Sol-gel based $\mathrm{TiO}_{2}$ thin film was applied on glazed wall tiles using spin coating. The deposited film was observed as crack free and homogeneous after curing at test temperatures. The film thickness was found to be $\sim 63 \mathrm{~nm}$ and $50 \mathrm{~nm}$ after curing at $750^{\circ} \mathrm{C}$ and $800^{\circ} \mathrm{C}$. Calcination of gel powder at $450^{\circ} \mathrm{C}$ results in crystalline titania with anatase phase and as the temperature increases from $600^{\circ} \mathrm{C}$ to $700^{\circ} \mathrm{C}$, anatase phase reduced and rutile phase increased and at $800^{\circ} \mathrm{C}$, only rutile phase was detected. Microstructure analysis of the thin film coated substrates showed nanocrystalline thin film at $700{ }^{\circ} \mathrm{C}$ and $750^{\circ} \mathrm{C}$ and at $800^{\circ} \mathrm{C}$, nano crystalline particles were found to be immersed in glassy matrix. Coated tiles showed high gloss in the range of 380-420 GU as compared to uncoated one ( $72 \mathrm{GU}$ ) with the rise in curing temperature from $600^{\circ} \mathrm{C}$ to $800^{\circ} \mathrm{C}$. The contact angle of water was $66 \pm 8^{\circ}$ for T600 compared to uncoated $45 \pm 10^{\circ}$ and it shows a descending trend as the temperature increases and T800 shows contact angle of $50 \pm 3^{\circ}$. $\mathrm{TiO}_{2}$ oxide thin film deposition on the glazed surface and subsequent curing at $800^{\circ} \mathrm{C}$ resulted a hardness of 5 Moh's which is higher as compared to the uncoated substrate (4 Moh's). Alkali resistance studies showed that coated substrates marked T800 showed superior resistance compared to uncoated. $\mathrm{TiO}_{2}$ thin film coated substrates cured at all the temperatures showed bacterial reduction percentage greater than $85 \%$. However, as the curing temperature increased, it was found to be reduced from $97 \%$ to $87 \%$. Above studies substantiate the potential effect of the Titania thin film coating reported herein for improvement not only the quality and aesthetic appeal but also the functional properties of the glazed ceramic wall tile.

\section{Acknowledgments}

The authors are thankful to the Director, CSIR-CGCRI, Kolkata for his permission to publish the paper. The authors acknowledge with thanks the help extended by all the members of Naroda Centre during different stages of this work. Thanks are also due to the members of X-ray \& SEM sections of CGCRI, Kolkata for helping in characterization of the samples. Authors also greatly acknowledge help of ATIRA, Ahmedabad, Gujarat for antibacterial testing and Industries Commissionerate, Govt. of Gujarat for sponsoring GAP 1207 project under which this study was carried out. 


\section{References}

1. S. Hata, Y. Kai, I.Yamanaka, H.Oosaki, K. Hirota and S. Yamazaki, JSAE Review. 21, 97(2000).

2. C. Hu, Y. Lan, J. Qu, X. Hu and A. Wang, J. Phys. Chem. B. 110, 4066 (2006).

3. K. V. S. Rao, B. Zhuo, J. M. Cox, K. Chiang, M. Brungs, R. Amal, J. Biomed.Nanotech. 2, (2006).

4. Y. Kikuchi, K. Sunada, T. Iyoda, K. Hashimoto and A. Fujishima, J. Photochem. Photobio. A: Chem. 106, 51 (1997).

5. K. Sunada, Y. Kikuchi, K. Hashimoto, A. Fujishima, Environ. Sci. Technol.32, 726 (1998).

6. I. P. Parkin and R. G. Palgrave, J. Mater. Chem., 15, 1689 (2005).

7. R. Galindo, C. Gargori, S. Cerro, J. Badenes and G. Monrós, Key. Eng. Mate. 423:47-53 (2010).

8. Zhao Qingnan $\mathrm{Yu}$ and Jiaguo Zhao Xiujian, China ceramics, 1999 DOI: CNKI:SUN:ZGTC.0.1999-01-004

9. MA Chun, MA Tie cheng and ZHOU Jing, J. Dalian Inst. Light Inoustry;1999-03, DOI: cnki:ISSN:1005-4014.0.1999-03-005

10. M.Machida, K. Norimoto and T. Kimura, J. Am. Ceram. Soc; 88(1), 95-100. (2005).

11. Li Chunhong and Chen Yuqing, J. Ceramics, Issue 1, 68-70 (2006).

12. S.Q. Sun, B.Sun, Wenquin Zhang and D. Wang, Bull. Mater. Sci. 31(1) 61-66 (2008).

13. J. Määttä, M. Piispanen., R. Kuisma, H.-R Kymäläinen, A.Uusi-Rauva, K.-R. Hurme, S.Areva, A.M. Sjöberg and L. Hupa, J.Euro Ceram Soc. 27, 4555-4560 (2007).

14. R. Kuisma, L.Fröberg, H.-R. Kymäläinen, E. Pesonen-Leinonen, M. Piispanen, P.Melamies, M. Hautala, A.-M. Sjöberg and L.Hupa. J. Euro Ceram Soc 27,101-108 (2007).

15. Technology Programme Report 17/2006. PINTA - Clean Surfaces 2002-2006. Final Report, Finnish Funding Agency for Technology and Innovation, Tekes. Libris Oy. 229.

16. M. Piispanen, J. Määttä, S. Areva, A.-M. Sjöberg, M. Hupa and L. Hupa, J. Euro Ceram Soc. 29, 1855-1860 (2009).

17. ASTM C 609-90 (Reapproved 1995) Standard Test method for measurement of small colour differences between ceramic wall or Floor tile. American Society for Testing and Materials, 100 Barr Harbour Dr, West Conshohocken PA 19428, 1-5, 1999.

18. S.Kumar, "Hand Book of Ceramics: Section -B", Vol.4, 537 -538, Kumar \& Associates, Calcutta, India, 1995.

19. ASTM D 523-89, Standard Test Method for Specular Gloss, American Society for Testing and Materials, 100 Barr Harbour Dr, West Conshohocken PA 19428, 1-5, 1999.

20. ISO: 10545: 1995(E) Ceramic Tiles Part 13, Determination of chemical resistance. $I^{\text {st }}$ Edition; International Organization for standardization: Switzerland, 1995; 1-5.

21. JIS Z 2801:2000, Antimicrobial products-Test for antimicrobial activity and efficacy, Japanese Standards Association, Tokyo, 107-8440, Japan.

22. C. J. Brinker, G.W. Scherer, Sol-Gel Science: The physics and chemistry of sol-gel processing, (Academic New York, 1990).

23. M. Cenea, J. Opto electron. and Adv. Materials, 7 (6), 3015-3022. (2005).

24. J. Partyka and M. Gajek, Interceram. 5, 270-276 (2012).

25. www.mindat.org

26. Su-Shia Lin, Ceram.Int. 38 (3), 2461-2466 (2012).

27. A.S.Guzenda, M.G. Lipman, H. Szymanowski, J. Kowalski, P. Wojcie-chowski, T. Halamus and A. Tracz, Thin solid films. 517, 5409-5414 (2009). 